\title{
Small-Scale Biofuel Production: Assessment of Efficiency
}

\author{
Olga Smirnova ${ }^{1}$, Ekaterina Kharitonova$^{2}$, Ivan Babkin ${ }^{1}$, Valentina Pulyaeva ${ }^{2}$, Mark Haikin ${ }^{3}$ \\ ${ }_{1}^{1}$ Peter the Great St. Petersburg Polytechnic University, 29, Politechnicheskaya St., St. Petersburg 195251, \\ Russia \\ ${ }^{2}$ Financial University under the Government of the Russian Federation, 49, Leningradsky Pr., Moscow \\ 125167, Russia \\ ${ }^{3}$ St. Petersburg Mining University, 2, 21 Lines, Vasilievsky Island, St. Petersburg 199106, Russia
}

\begin{abstract}
Currently, the energy industry is tending toward a global expansion of the use of renewable energy sources, thereby contributing to economic development. In the Russian Federation, such transformation is particularly important in terms of enhancing the involvement of excessive wood waste in production. In this regard, processing wood waste into pellets has proven to be highly beneficial. Apart from increasing the efficiency of the harvested wood and reducing the fire hazard in waste storages, it also positively influences the structure of energy balance in specific regions, creating an impetus for the development of small businesses in the country. This paper aims to assess the economic effects of biofuel production together with the efficiency of processing wood waste into pellets as a factor in the development of small business in the Russian Federation. Net present value (NPV) is used as the main analytical tool to assess economic efficiency. A general scientific analysis of the open data is also applied, including analytical reviews of the Russian ministries and international organizations. As a result, the paper estimates the prospects of using wood biomass in the energy industry, provides options for establishing capacities of microenterprises engaged in pellet production, and considers the expected economic effect for various levels of capacity utilization. The scientific novelty of this paper is centered on the design of a biofuel production scheme from wood waste (wood pellets) for a small-business enterprise with minimum labor and production costs. The paper is highly practice oriented, as it substantiates the economic efficiency of pellet production by small businesses in the Russian Federation in accordance with current legislation and state subsidies. Overall, this paper provides enough evidence to seriously consider the prospects of wood pellet production in order to expand the share of renewable sources in the energy balance of the country.
\end{abstract}

Keywords: Biofuels; Economic efficiency; Renewable energy source; Small business; Wood pellets

\section{Introduction}

One of the most important trends observed in the global energy market is its gradual shift toward wider use of renewable energy sources (RES). This transformation is extremely beneficial for the Earth's climate, as the gradual abandonment of carboncontaining fuel and energy resources (FERs) leads to a significant reduction in carbon dioxide $\left(\mathrm{CO}_{2}\right)$ emissions. Though the decarbonization of energy is taking place worldwide, its intensity in different regions is determined by numerous factors, such as the level of

${ }^{*}$ Corresponding author's email: ivan.babkin@spbstu.ru, Tel.: +007 -812- 534-73-31

doi: 10.14716/ijtech.v12i7.5401 
technological development (Budiyanto et al., 2011; Qosasi et al., 2019), the prospects of environmental legislation, the availability of natural energy resources, and the role of specific countries in the international division of labor (Konnikov et al., 2020).

Industrially developed countries widely promote respect for nature by developing and implementing technologies that preserve the environment, thus automatically transforming the fuel and energy balance (FEB), both within individual countries and globally (Nayaka and Bhushan, 2019; Shahbaz et al., 2020; Vankov et al., 2020). According to previous studies, the economic success of RES development depends on the utilization of various biomasses that can be processed and used as environmentally friendly biological fuels, thereby replacing primary FERs (Ugwua and Enweremadu, 2019).

Wood pellets have been gaining popularity in the global energy market since the second decade of the $21^{\text {st }}$ century and have steadily increased in production and consumption, which is expected to exceed 40 million tons and a total value of more than $\$ 9$ billion by 2020. Significantly enough, the most drastic increase has been observed in the recent decade when the figures doubled. Despite certain fluctuations in statistics on production and consumption, the global demand for wood pellets is expected to increase to at least $\$ 18$ billion by 2027. Remarkably, almost half of the pellets' volume is produced in North America (the United States and Canada) and China. According to the 2020 data, Russia ranks fifth among world leaders, with an annual production of about 2 million tons (Gemco Energy, n.d.). The bigger picture shows that Russian pellet exports did not exceed 0.9 million tons in 2015. If such a pace of development is maintained, Russia will be able to move up to the second position among the world's leading exporters, following the United States, leaving Canada, China, and the Baltic States behind.

Europe is the main consumer of wood pellets in the world (Statista, 2019). In turn, North America is expected to see a growing demand for pellets by an average of 7-8\% per year due to the gradual abandonment of the consumption of hydrocarbon FERs (Gemco Energy, n.d.).

Wood pellets are produced and consumed at greater rates, as the reserves of easily mined FERs are drying out, and the effects human activity cannot be neglected any longer (Picchio et al., 2020). As a response to these urgent problems, timber waste can be effectively used in the production of wood pellets, especially taking into account the fact that its share sometimes reaches more than $15 \%$ of the initial raw materials. What is more, environmental problems associated with the need to store these wastes are becoming less acute (Scherhaufer et al., 2018).

Since the pellets are produced without any chemical additives, they are currently considered the most environmentally friendly biofuel used. In addition, when burning, the pellets emit the same amount of $\mathrm{CO}_{2}$ as during the natural decomposition of wood (Sippula et al., 2017). What is more, wood in general has been proven to exert less damage on the environment compared to fuel oil (Paolotti et al., 2017).

This paper aims to assess the efficiency of wood pellet production as a factor in the development of small business in the Russian Federation. To achieve this goal, the paper aims to do the following:

1. Evaluate the prospects of using wood biomass to maintain the country's FEB.

2. Develop a range of capacities potentially applied by the microenterprises engaged in pellet production.

3. Calculate the expected economic effects of different production capacities.

The scientific novelty of the research is centered on the design of biofuel production from wood waste (wood pellets) by a small-business enterprise with minimum labor and production costs. 


\section{Literature Review}

The topic of RES is widely covered and discussed by the academic community. Such a large-scale concern is explained by the fact that many countries are actively looking for alternative raw materials to produce fuel pellets. Each state has opted for different materials, for instance, miscanthus (France) (Perrin et al., 2017), straw (China) (Song et al., 2017), forest biomass (Australia) (Crawford et al., 2016), plum pits (Poland) (Kostic et al., 2016), tea and oil palm waste (Malaysia) (Pua et al., 2020), tobacco (Chen et al., 2016), sugar beet (Poland) (Modelska et al., 2017), coffee waste (Lisowski et al., 2019; Colantoni et al., 2021), beans and potato peel (Obidziński, 2014; Minajeva et al., 2018), and olive pomace and olive tree (Barbanera et al., 2016). In particular, Thailand is currently experiencing a rapid increase in the production of wood pellets from fast-growing trees (Saosee et al., 2020).

Another good example is Canada, where large forests and wood biomass are typical, similar to in Russia, and thus, biofuels can be produced from wood waste (bark and branches, wood chips, scraps, sawdust, etc.) (Dupuis et al., 2021). As a huge benefit for all stakeholders, scientists have successfully investigated the effectiveness of bioenergy in remote settlements in Canada and have proven the feasibility of coordinated action between manufacturers and consumers of biofuels (Chen et al., 2016; Buchholz et al., 2017).

Though the issues of environmental and economic development are still relevant (Kichigin, 2017), the situation in Russia differs greatly from the Canadian case. The country does not get sufficient development of initiatives in RES (Shabunina et al., 2017), particularly due to a shortage of qualified specialists (Putinceva et al., 2020). Another problem faced by the industry is that small businesses involved in RES are not sufficiently supported (Khadra et al., 2020).

The combination of factors mentioned above highlights the relevance of discussing the issue of pellet production by small businesses as an RES option.

\section{Materials and Methods}

The production of wood pellets involves pressing and drying flour-like wood waste and subsequently shaping it into pellets. Throughout this process, lignin (a component of wood) softens and glues the prepared wood waste into dense cylinders, which makes the production process chemical free. The flow rate of wood waste per 1 ton of pellets amounts to $3-5 \mathrm{~m}^{3}$ of natural moisture waste (Abdoli et al., 2018). Pellets vary in diameter from 4 to $12 \mathrm{~mm}$ and in length from 20 to $50 \mathrm{~mm}$.

When compared to other fuels, wood pellets:

- reduce emissions of air pollutants because wood biofuels are considered $\mathrm{CO}_{2}$ neutral;

- provide a higher calorific value compared to firewood and wood chips (energy content of $1 \mathrm{~kg}$ of wood pellets is equivalent to 0.5 liters of diesel fuel);

- cost less compared to diesel fuel and electric energy;

- enable the use of the pellet boiler with all due convenience; and

- ensure conditions for the boiler houses to operate independently (Sippula et al., 2017).

The pellet production line includes zones for receiving, feeding, storing, drying, grinding, granulating (pressing), and cooling, as well as final packing. Production of 1 ton of pellets requires from 30 to $50 \mathrm{~kW} / \mathrm{h}$ of electricity. Three types of packing are available: in bulk, in large bags (from 500 to $1200 \mathrm{~kg}$ ), and in small packages (from 10 to $20 \mathrm{~kg}$ ). Usually, large power plants opt for pellets to be shipped in bulk because the quality requirements are not very high, which allows them to purchase at a lower price. In turn, low-capacity boilers require small packages, which leads to an increase in the price per 1 ton of wood 
pellets (Pantaleo et al., 2020).

This paper uses statistical methods, economic analysis, and synthesis of data on the effectiveness of business projects (Babkin et al., 2015, Babkin et al., 2019). The economic efficiency of the business plan for pellet production is calculated on the basis of the net present value (NPV). The research data are sourced from the Federal State Statistics Service, the Ministry of Energy, the Ministry of Industry and Trade of the Russian Federation, and the Institute of Energy Research of the Russian Academy of Sciences, along with results from previous studies on the use of wood biomass as a RES, published in leading peer-reviewed journals.

To evaluate the economic efficiency of wood pellet production at a small enterprise in Russia, the authors applied the following algorithm:

1) Drew up a brief summary of investment costs involved in setting up a microenterprise to produce wood pellets from the timber industry complex waste based on publicly available data on the cost of the necessary equipment and preparation of organizational documentation. To optimize investment costs, the authors assumed that such a small enterprise would be created with an already existing large sawmill.

2) Calculated the annual production capacity of a microenterprise within three modes of production (in one, two, or three shifts), based on the technical characteristics of the equipment (production capacity, required preventive repairs, maintenance, etc.), and the planned fund of the enterprise per year, based on the production calendar in Russia.

3) Evaluated the annual operating expenses for maximum production under the current tax legislation of the Russian Federation on the basis of publicly available information on the cost of consumables, packaging, electricity, etc.

4) Assessed the financial results in a pellet-producing microenterprise according to the minimum sale prices in the domestic biofuel market. At this stage, the authors assumed that the small enterprise would apply the preferential taxation system operating in the territory of the Russian Federation-"simplified taxation system."

5) Calculated the present value for a typical project and determined its payback period according to the following formula:

$$
N P V=x_{o}+\frac{x_{1}}{(1+k)}+\frac{x_{2}}{(1+k)^{2}}+\cdots+\frac{x_{n}}{(1+k)^{n}}
$$

where $x_{i}$ is the cash flow of the project for the $i$-th period, and $k$ is the required rate of return (as an assumption, the authors took the rate of return at a level of 10\%).

\section{Results}

The initial launch of a microenterprise engaged in pellet production requires exact funds, permits for access to operating networks, and a range of specific technological capabilities (e.g., constantly renewable stocks of wood waste). It is also necessary to develop sufficient technical, technological, and logistical solutions that ensure the delivery of pellets to consumers according to the time, volume, and quality requirements.

Table 1 considers the economic aspects of launching a microenterprise as an external or internal organization at large logging plants, with the aim of optimizing investment costs (Table 1).

The production capacity of a business is determined by its operation mode (Table 2) and the hourly capacity of the line (300 kg of wood pellets per hour). Considering that an average household boiler consumes 3-5 tons of wood pellets per season, a pellet-producing enterprise must have at least 100 regular customers or an exporting wholesale customer, even if operating in one shift. 
Table 1 Business plan provisions for the pellet production line with a $300 \mathrm{~kg} / \mathrm{h}$ capacity

\begin{tabular}{lc}
\hline \multicolumn{1}{c}{ Initial priority investments } & Funds, thousand rubles \\
\hline Cost of equipment with installation (dry raw materials) & 3640.0 \\
Working capital & 280.0 \\
Organizational expenses & 40.0 \\
Total expenses & 3960.0 \\
\hline
\end{tabular}

Designed by the authors on the basis of data on the cost of equipment and their economic calculations.

Table 2 Production capacity of the production line with a 5-day working week

\begin{tabular}{lcrrr}
\hline \multicolumn{1}{c}{ Indicators } & Unit of & \multicolumn{3}{c}{ Operating mode } \\
\cline { 3 - 5 } & measure & 1 shift & 2 shifts & 3 shifts \\
\hline Planned fund of working time per year & hour & 2100 & 4200 & 6300 \\
Scheduled repairs and maintenance breaks & $\%$ & 5.0 & 10.0 & 12.0 \\
Working hours per year & hour & 1995 & 3780 & 5544 \\
Production per 1 hour of work & ton & 0.3 & 0.3 & 0.3 \\
Possible production (maximum per year) & ton & 598.5 & 1134.0 & 1663.2 \\
\hline
\end{tabular}

Designed by the authors on the basis of technical data on the operation of equipment and their economic calculations

Business-related operating costs (Table 3) are classified into semiconstant and semivariable. Note that one production worker per shift is enough to maintain the entire line. In accordance with Chapter 34, "Insurance Premiums," of the Tax Code of the Russian Federation, insurance contributions are calculated on the basis of the wage fund at 31.4\%, including statutory pension insurance at 22\%; compulsory social insurance at 2.9\%; compulsory health insurance at 5.1\%; and compulsory social insurance for accidents at work and occupational diseases at $1.4 \%$ (due to group XIII, professional risk) (Tax Code of the Russian Federation, 2000). The estimated useful life of production equipment is 120 months when working in one shift, 90 months for two shifts, and 60 months for three shifts. The price of $1 \mathrm{~m}^{3}$ of sawdust is 150 rubles, and $4 \mathrm{~m}^{3}$ of sawdust produces approximately 1 ton of pellets. The price of packaging and other materials (for production of 1 ton) is 280 rubles, electricity is 1 thousand rubles, and transportation costs are 800 rubles.

Table 3 Annual operating business-related expenses, thousand rubles

\begin{tabular}{lccc}
\hline & \multicolumn{3}{c}{ Operating mode (production of pellets, tons) } \\
\cline { 2 - 4 } \multicolumn{1}{c}{ Indicators } & $\begin{array}{c}1 \text { shift } \\
(598.5 \mathrm{t})\end{array}$ & $\begin{array}{c}2 \text { shifts } \\
(1.134 .0 \mathrm{t})\end{array}$ & $\begin{array}{c}3 \text { shifts } \\
(1.663 .2 \mathrm{t})\end{array}$ \\
\hline Labor compensation fund & 600.0 & 1200.0 & 1800.0 \\
\hline Accruals to the labor compensation fund & 188.4 & 376.8 & 565.2 \\
\hline Rent (including utilities, except electricity for & 280.0 & 280.0 & 280.0 \\
pellet production) & & & \\
Depreciation & 364.0 & 485.3 & 728.0 \\
For reference: amount of accrued depreciation & 30.33 & 40.44 & 60.67 \\
for 1 month of equipment operation & & & 300.0 \\
\hline Management services & 300.0 & 300.0 & 200.0 \\
\hline Advertising expenses & 200.0 & 200.0 & $\mathbf{3 8 7 3 . 2}$ \\
\hline Total semifixed expenses & $\mathbf{1 9 3 2 . 4}$ & $\mathbf{2 8 4 2 . 1}$ & 997.9 \\
\hline Sawdust cost & 359.1 & 680.4 & 465.7 \\
Cost of packaging and other materials & 167.6 & 317.5 & 1663.2 \\
Electricity & 598.5 & 1134.0 & 1330.6 \\
Transportation costs & 478.8 & 907.2 & $\mathbf{4 4 5 7 . 4}$ \\
\hline Total semivariable expenses & $\mathbf{1 6 0 4 . 0}$ & $\mathbf{3 0 3 9 . 1}$ & $\mathbf{8 3 3 0 . 6}$ \\
\hline Total operating costs & $\mathbf{3 5 3 6 . 4}$ & $\mathbf{5 8 8 1 . 2}$ & \\
\hline
\end{tabular}

Designed by the authors on the basis of their economic calculations 
If production is carried out in one, two, or three shifts, with the general line load at $75 \%$, the designed capacity is reached in the second operation year (Table 4). According to Chapter 26.2, "Simplified Taxation System," of the Tax Code of the Russian Federation, the tax can be calculated as $15 \%$ of the difference between income and expenses, but not less than $1 \%$ of the annual revenue. The estimated price for 1 ton of wood pellets is taken as the lowest in the domestic market-7 thousand rubles per 1 ton. At the same time, the alignment of internal and external prices for wood pellets increases the efficiency of a microenterprise, making the biofuel business more attractive.

Table 4 Net profit of a small enterprise engaged in pellet production in 1 shift, thousand rubles

\begin{tabular}{|c|c|c|c|c|c|c|}
\hline \multirow[b]{2}{*}{ Indicators } & \multicolumn{2}{|c|}{$1 \mathrm{shift}$} & \multicolumn{2}{|c|}{2 shifts } & \multicolumn{2}{|c|}{3 shifts } \\
\hline & $\begin{array}{c}\text { First year } \\
(75 \%)\end{array}$ & $\begin{array}{l}\text { Second } \\
\text { year }\end{array}$ & $\begin{array}{c}\text { First year } \\
(75 \%)\end{array}$ & $\begin{array}{c}\text { Second } \\
\text { year }\end{array}$ & $\begin{array}{c}\text { First year } \\
(75 \%)\end{array}$ & $\begin{array}{c}\text { Second } \\
\text { year }\end{array}$ \\
\hline $\begin{array}{l}\text { Production of pellets when } \\
\text { working in } 1 \text { shift, ton }\end{array}$ & 448.9 & 598.5 & 850.5 & 1134.0 & 1247.4 & 1663.2 \\
\hline Company revenue & 3142.3 & 4189.5 & 5953.5 & 7938.0 & 8731.8 & 11642.4 \\
\hline Production cost, including: & 3135.4 & 3536.4 & 5121.4 & 5881.2 & 7216.3 & 8330.6 \\
\hline Semifixed expenses & 1932.4 & 1932.4 & 2842.1 & 2842.1 & 3873.2 & 3873.2 \\
\hline $\begin{array}{l}\text { Semivariable expenses } \\
\text { (75\% in the } 1 \text { st year) }\end{array}$ & 1203.0 & 1604.0 & 2279.3 & 3039.1 & 3343.1 & 4457.4 \\
\hline Gross profit & 6.9 & 653.1 & 832.1 & 2056.8 & 1515.5 & 3311.8 \\
\hline $\begin{array}{l}\text { Tax under the simplified } \\
\text { taxation system }\end{array}$ & 31.4 & 98.0 & 124.8 & 308.5 & 227.3 & 496.8 \\
\hline Net profit & -24.5 & 555.1 & 707.3 & 1748.3 & 1288.2 & 2815.0 \\
\hline
\end{tabular}

Designed by the authors on the basis of Tables 1-3

The NPV of the project (Table 5) indicates that, by varying the level of the workload at a processing line and managing the operating costs, it is possible to ensure effective pellet production at an enterprise. Working in one shift will pay off in six years, which is reduced to five years once a subsidy to compensate for transportation costs is obtained. The payback period is significantly reduced if the work is performed in two or three shifts, provided that there is a sales market, primarily exporting. Additionally, a state subsidy up to $80 \%$ of the transport costs is available, which amounts to at least 400 thousand rubles annually.

Table 5 Calculation of NPV for the production line with a $300 \mathrm{~kg} / \mathrm{h}$ capacity

\begin{tabular}{lcccccc}
\hline \multicolumn{1}{c}{ Indicators } & 1 year & 2 year & 3 year & 4 year & 5 year & 6 year \\
\hline Number of equipment shifts & 1 & 1 & 2 & 2 & 3 & 3 \\
Production capacity, thousand tons & $75 \%$ & $100 \%$ & $75 \%$ & $100 \%$ & $75 \%$ & $100 \%$ \\
Production capacity, thousand tons & 0.449 & 0.598 & 0.850 & 1.134 & 1.247 & 1.663 \\
Investment, million rubles & 3.960 & - & - & - & - & - \\
Estimated revenue, million rubles & 3.142 & 4.189 & 5.983 & 7.938 & 8.732 & 11.642 \\
Operating expenses, million rubles & 3.135 & 3.536 & 5.121 & 5.881 & 7.216 & 8.330 \\
Net present value, million rubles & 0.007 & 0.653 & 0.832 & 2.057 & 1.515 & 3.312 \\
Present NPV, million rubles & 0.007 & 0.593 & 0.687 & 1.545 & 1.035 & 2.056 \\
\hline
\end{tabular}

Designed by the authors on the basis of Tables 2-5 and their economic calculations

Overall, a small pellet-producing enterprise provides a significant reduction in storage costs and allows for gaining income from processing wood waste even at low prices, despite the necessary initial investments in basic equipment.

In the study, the main causes of medication error found are information overload and 
fatigue. To overcome the first of these, suggestions made include using computerized systems to reduce errors in reading the handwriting of the doctors and in drug labeling. To minimize fatigue, rearrangement of shift hours as well as rest time is suggested.

\section{Discussion}

Today, the feasibility of using various types of RES is an important issue on the research agenda worldwide. For instance, Italian scientists conducted a study on the pellet market in Italy (Pantaleo et al., 2020) and assessed its profitability in accordance with different raw material prices, moisture levels, and transportation costs. As a result of this comprehensive research, the profitability of production was proven to increase alongside improving biomass quality. This study is similar to the one carried out by the Italian counterparts. However, the results presented in this paper differ greatly, as the main goal here was to assess the economic efficiency of pellet production in small businesses in the Russian economic environment.

It should be noted that the use of wood pellets in industrial production and everyday life is quite economical. At lower consumption, they emit more heat energy than alternative fuels (Table 6), and the efficiency of boilers when operating on wood pellets can reach up to $90 \%$.

Table 6 Specific heat of combustion of some fuels

\begin{tabular}{|c|c|c|c|c|c|c|c|}
\hline \multirow{2}{*}{ Type of fuel } & \multirow[b]{2}{*}{ Unit } & \multicolumn{3}{|c|}{ Specific heat of combustion } & \multicolumn{3}{|c|}{ Equivalent } \\
\hline & & kcal & kw & MJ & $\begin{array}{c}\text { Natural gas, } \\
\mathrm{m}^{3} \\
\end{array}$ & $\begin{array}{c}\text { Diesel fuel, } \\
1 \\
\end{array}$ & $\begin{array}{c}\text { Fuel oil, } \\
1\end{array}$ \\
\hline Electricity & $1 \mathrm{kWh}$ & 864 & 1.0 & 3.62 & 0.108 & 0.084 & 0.089 \\
\hline Diesel fuel & 11 & 10300 & 11.9 & 43.12 & 1.288 & - & 1.062 \\
\hline Petrol & 11 & 10500 & 12.2 & 44.0 & 1.313 & 1.019 & 1.082 \\
\hline Natural gas & $1 \mathrm{~m}^{3}$ & 8000 & 9.3 & 33.5 & - & 0.777 & 0.825 \\
\hline Liquefied gas & $1 \mathrm{~kg}$ & 10800 & 12.5 & 15.2 & 1.350 & 1.049 & 1.113 \\
\hline Hard coal $(W=10 \%)$ & $1 \mathrm{~kg}$ & 6450 & 7.5 & 27.00 & 0.806 & 0.626 & 0.665 \\
\hline Brown coal $(W=3040 \%)$ & $1 \mathrm{~kg}$ & 3100 & 3.6 & 12.98 & 0.388 & 0.301 & 0.320 \\
\hline Charcoal & $1 \mathrm{~kg}$ & 6510 & 7.5 & 27.26 & 0.814 & 0.632 & 0.671 \\
\hline Peat & $1 \mathrm{~kg}$ & 2900 & 3.6 & 12.10 & 0.363 & 0.282 & 0.299 \\
\hline Wood pellet & $1 \mathrm{~kg}$ & 4100 & 4.7 & 17.17 & 0.513 & 0.938 & 0.423 \\
\hline Dried wood $(W=20 \%)$ & $1 \mathrm{~kg}$ & 3400 & 3.9 & 14.24 & 0.425 & 0.330 & 0.351 \\
\hline Sawdust & $1 \mathrm{~kg}$ & 2000 & 2.3 & 8.37 & 0.250 & 1.194 & 0.206 \\
\hline
\end{tabular}

Nonetheless, the results obtained by the authors do not contradict previous studies published in the leading international journals and can be applied in further research on the effectiveness of waste-related RES. This paper may be used in the comparative assessment of various technologies involved in the production of wood biofuels that depend on such variables as raw materials, regional subsidies in the Russian Federation, or even different countries of the world.

\section{Conclusions}

According to the results obtained from this paper, Russia shows sufficient potential to transform the energy balance toward a wider use of RES, including wood biomass, which, for now, remains largely unclaimed, posing a fire-related threat to storage areas. The economic calculations allow for the conclusion that pellet production in micro-business conditions is viable. In addition, with a production capacity of $300 \mathrm{~kg} / \mathrm{h}$, it would pay off 
within six years, even at a minimum selling price, and if a transportation subsidy were acquired, this period would be reduced to five years. Taking into account real global prices, investments in the wood pellet business may turn out to be twice as lucrative, provided that no force majeure takes place and that proper competitiveness of Russian production is ensured. Having considered three modes of capacity utilization, we can conclude that profit can be obtained in the second operation year and, with greater capacity utilization, in the first year.

\section{References}

Abdoli, M.A., Golzary, A., Hosseini, A., Sadeghi, P., 2018. Wood Pellet as a Renewable Source of Energy from Production to Consumption. Springer, Cham, Switzerland

Babkin, A.V., Vertakova, Y.V., 2015. Methods for the Assessment of the Economic Potential of an Industrial Enterprise: Analysis and Characterization. In: Proceedings of the $25^{\text {th }}$ International Business Information Management Association Conference-Innovation Vision 2020: From Regional Development Sustainability to Global Economic Growth, IBIMA, pp. 1294-1302

Babkin, A.V., Kuzmina, S.N., Oplesnina, A.V., Kozlov, A.V., 2019. Selection of Tools of Automation of Business Processes of a Manufacturing Enterprise. In: Proceedings of the 2019 IEEE International Conference Quality Management, Transport and Information Security, Information Technologies IT and QM and IS, pp. 226-229

Barbanera, M., Lascaro, E., Stanzione, V., Esposito, A., Altieri, R., Bufacchi, M., 2016. Characterization of Pellets from Mixing Olive Pomace and Olive Tree Pruning. Renewable Energy, Volume 88 pp. 185-191

Buchholz, T., Gunn, J.S., Saah, D.S., 2017. Greenhouse Gas Emissions of Local Wood Pellet Heat from Northeastern US Forests. Energy, Volume 141, pp. 483-491

Budiyanto, B., Setiabudy, R., Setiawan, E.A., Sudibyo, U.B., 2011. Development of Direct Current Microgrid Control for Ensuring Power Supply from Renewable Energy Sources. International Journal of Technology, Volume 2(3), pp. 199-206

Chen, H., Guo, Y., Wang, F., Wang, G., Qi, P., Guo, X., Dai, B., Yu, F., 2016. An Activated Carbon Derived from Tobacco Waste for Use as a Supercapacitor Electrode Material. New Carbon Materials, Volume 32(6), pp. 592-599

Colantoni, A., Paris, E., Bianchini, L., Ferri, S., Marcantonio, V., Carnevale, M., Palma, A., Civitarese, V., Galluci, F., 2021. Spent Coffee Ground Characterization, Pelletization Test and Emissions Assessment in the Combustion Process. Scientific Reports, Volume 11, pp. $1-14$

Crawford, D.F., O'Connor, M.H., Jovanovic, T., Herr, A., Raison, R.J., O'Connell, D.A., Baynes, T., 2016. A Spatial Assessment of Potential Biomass for Bioenergy in Australia in 2010, and Possible Expansion by 2030 and 2050. GCB Bioenergy, Volume 8, pp. 707-722

Dupuis, É., Thiffault, E., Barrette, J., Adjallé, K., Martineau, C., 2021. Bioenergy Conversion Potential of Decaying Hardwoods. Energies, Volume 14(1), pp. 1-21

Gemco Energy, n.d. Wood Pellet Market in Europe, North America and Asia. Available Online at www.gemcopelletmills.com/wood-pellet-market.html, Accessed on June 10, 2021

Khadra, J.B., Goncharova, N.L., Radwan, Y., 2020. Regional Aspects the Small and Medium Enterprises and Their Impact on the Social and Economic Development. In: Proceedings of the 33 $3^{\text {rd }}$ International Business Information Management Association Conference, IBIMA 2019: Education Excellence and Innovation Management through Vision 2020, Granada, Spain, April 2019, pp. 10-11

Kichigin, O.E., 2017. Fossil Fuel Production Impact on Regional Eco-Economic Development. International Journal of Ecological Economics and Statistics, Volume 38, pp. 12-22 
Konnikov, E.A., Dubolazova, Y.A., Mansurov, R.D., 2020. Dialectics of the Renewable Energy Market. In: Proceedings of the European Conference on Innovation and Entrepreneurship, ECIE, pp. 952-960

Kostic, M.D., Velickovic, A.V., Jokovic, N.M., Stamenkovic, O.S., Veljkovic, V.B., 2016. Optimization and Kinetic Modeling of Esterification of the Oil Obtained from Waste Plum Stones as a Pretreatment Step in Biodiesel Production. Waste Management, Volume 48, pp. 619-629

Lisowski, A., Olendzki, D., Swietochowski, A., Dabrowska, M., Mieszkalski, L., OstrowskaLigeza, E., Stasiak, M., Klonowski, J., Piatek, M., 2019. Spent Coffee Grounds Compaction Process: Its Effects on the Strength Properties of Biofuel Pellets. Renewable Energy, Volume 142, pp. 173-183

Minajeva, A., Jasinskas, A., Romaneckas, K., Aboltins, A., 2018. Evaluation of Fodder Bean Waste Utilization for Energy Purpose. Engineering for Rural Development, Volume 17, pp. 1771-1776. Available Online at http://www.tf.llu.lv/conference/proceedings2018/ Papers/N315.pdf, Accessed on June 10, 2021

Modelska, M., Berlowska, J., Kręgiel, D., Cieciura, W., Antolak, H., Tomaszewska, J., Binczarski, M., Szubiakiewicz, E., Witońska, I., 2017. Concept for Recycling Waste Biomass from the Sugar Industry for Chemical and Biotechnological Purposes. Molecules, Volume 22(9), pp. 1-26

Nayaka, A., Bhushan, B., 2019. An Overview of the Recent Trends on the Waste Valorization Techniques for Food Waste. Journal of Environmental Management, Volume 233, pp. 352-370

Obidziński, S., 2014. Pelletization of Biomass Waste with Potato Pulp Content. International Agrophysics, Volume 28, pp. 85-91

Pantaleo, A., Villarini, M., Colantoni, A., Carlini, M., Santoro, F., Rajabi Hamedani, S., 2020. Techno-Economic Modeling of Biomass Pellet Routes: Feasibility in Italy. Energies, Volume 13(7), pp. 1-15

Paolotti, L., Martino, G., Marchini, A., Boggia, A., 2017. Economic and Environmental Assessment of Agro-Energy Wood Biomass Supply Chains. Biomass Bioenergy, Volume 97, pp. 172-185

Perrin, A., Wohlfahrt, J., Morandi, F., Østergård, H., Flatberg, T., De La Rua, C., Gabrielle, B., 2017. Integrated Design and Sustainable Assessment of Innovative Biomass Supply Chains: A Case-Study on Miscanthus in France. Applied Energy, Volume 204, pp. 66-77

Picchio, R., Latterini, F., Venanzi, R., Stefanoni, W., Suardi, A., Tocci, D., Pari, L., 2020. Pellet Production from Woody and Non-Woody Feedstocks: A Review on Biomass Quality Evaluation. Energies, Volume 13, pp. 1-20

Pua, F.L., Subari, M.S., Ean, L.W., Krishnan, S.G., 2020. Characterization of Biomass Fuel Pellets Made from Malaysia Tea Waste and Oil Palm Empty Fruit Bunch. Materials Today: Proceedings, Volume 31, pp. 187-190

Putinceva, N., Ivanova, M., Liubarskaia, M., Ghosh, S.K., 2020. Implementation of Renewable Energy Sources in the Russian Energy System: Opportunities and Threats. In: ACM International Conference Proceeding Series, Article 47, pp. 1-8

Qosasi, A., Maulina, E., Purnomo, M., Muftiadi, A., Permana, E., Febrian, F., 2019. The Impact of Information and Communication Technology Capability on the Competitive Advantage of Small Businesses. International Journal of Technology, Volume 10(1), pp. 167-177

Saosee, P., Sajjakulnukit, B., Gheewala, S.H., 2020. Life Cycle Assessment of Wood Pellet Production in Thailand. Sustainability, Volume 12(17), pp. 1-22

Scherhaufer, S., Moates, G., Hartikainen, H., Waldron, K., Obersteiner, G., 2018. Environmental Impacts of Food Waste in Europe. Waste Management, Volume 77, pp. 98-113 
Shabunina, T.V., Shchelkina, S.P., Rodionov, D.G., 2017. An Innovative Approach to the Transformation of Eco-Economic Space of a Region based on the Green Economy Principles. Academy of Strategic Management Journal, Volume 16(1), pp. 176-182

Shahbaz, M., Raghutla, C., Chittedi, K.R., Jiao, Z., Vo, X.V., 2020. The Effect of Renewable Energy Consumption on Economic Growth: Evidence from the Renewable Energy Country Attractive Index. Energy, Volume 207, https://doi.org/10.1016/j.energy.2020.118162

Sippula, O., Lamberg, H., Leskinen, J., Tissari, J., Jokiniemi, J., 2017. Emissions and Ash Behavior in a $500 \mathrm{~kW}$ Pellet Boiler Operated with Various Blends of Woody Biomass and Peat. Fuel, Volume 202, pp. 144-153

Song, S., Liu, P., Xu, J., Chong, C., Huang, X., Ma, L., Li, Z., Ni, W., 2017. Life Cycle Assessment and Economic Evaluation of Pellet Fuel from Corn Straw in China: A Case Study in Jilin Province. Energy, Volume 130, pp. 373-381

Statista, 2019. Import Volume of Wood Pellets Worldwide in 2019, by Major Country. Available Online at https://www.statista.com/statistics/477057/imports-of-woodpellets-volume-by-key-country/ Accessed on 3 November, 2021

Tax Code of the Russian Federation (part two), 2000 N 117-FZ (as amended on 29.11.2021), Available Online at https://cis-legislation.com/document.fwx?rgn=1717

Ugwua, S.N., Enweremadu, C.C., 2019. Effects of Pre-Treatments and Co-Digestion on Biogas Production from Okra Waste. Journal of Renewable and Sustainable Energy, Volume 11(1), https://doi.org/10.1063/1.5049530

Vankov, J., Rotach, R., Laptev, S., Ziganshin, S., Afanaseva, O., 2020. Introduction of a Steam Screw-Rotor Machine to Improve the Energy and Economic Efficiency of Chemical Enterprises. International Journal of Technology, Volume 11(8), pp. 1628-1639 